\title{
PENERAPAN PDCA DALAM MEMINIMASI DEFECT SALAH VARIAN PANEL DASH JOIN FRONT DI PT.XYZ
}

\author{
Agung Prasetyo Senoaji ${ }^{{ }^{*}}$, M Kosasih ${ }^{1}$, Nelfiyanti ${ }^{1}$, Renty Anugerah Mahaji Puteri ${ }^{1}$ \\ Jurusan Teknik Industri, Fakultas Teknik Universitas Muhammadiyah Jakarta \\ Jl. Cempaka Putih Tengah 27 Jakarta Pusat 10510 \\ *Email : agungprasetyosenoaji@yahoo.com
}

\begin{abstract}
ABSTRAK
PT. adalah perusahaan yang bergerak dibidang otomotif di Indonesia yang memproduksi kendaraan roda empat, salah satunya adalah unit pick up D30N. Dalam proses produksinya, permasalahan utama yang dialami adalah masalah kualitas. Berdasarkan data defect yang didapatkan dari September 2017 hingga Februari 2018, permasalahan utama terdapat pada jalur Under Front yang memiliki defect terbesar yaitu Salah Varian Panel Dash Join Front Floor sebanyak 25 item, yang termasuk dalam kategori defect function. Sedangkan target manajemen untuk defect function yaitu 0 item. Selain itu, defect tersebut menyumbang kerugian akibat part scrap sebanyak 12 pcs dengan jumlah kerugian Rp 1.637.569,- dalam periode September 2017 sampai bulan Februari 2018. Kegiatan perbaikan yang dilakukan untuk mengatasi permasalahan yang ada dengan menerapkan metode Plan-Do-CheckAction (PDCA). Dari hasil analisis penyebab masalah, didapatkan beberapa implementasi perbaikan yaitu dengan menambahkan papan pengecekan WOS, membuat display pengecekan varian, mengurangi buffer stock, membuat identitas penempatan dolly, dan identitas varian pada dolly.Dari kegiatan perbaikan tersebut, defect Salah Varian Panel Dash Join Front Floor dapat diturunkan dari 25 item menjadi 0 item pada bulan Mei sampai Juni 2018 dan jumlah part scrap dari 12 pes menjadi 0 sehingga kerugian akibat scrap menjadi menurun. Sehingga target manajemen untuk defect tersebut dapat tercapai.
\end{abstract}

Kata Kunci: Kualitas, Defect, $P D C A$

\section{ABSTRACT}

PT. XYZ is one of the automotive companies in Indonesia that produces four-wheel vehicle, one of their products is a D30N pick up. In the production process, the main problem is quality problem. According to data of defects from September 2017 to February 2018, the main problem is at Under Front Line that has the largest defects among the others. The defect is Wrong Variant Panel Dash Join Front Floor with an amount of that defect is 25 item, which is included in the category of function defect. While the target of management for function defect is 0 item. Besides that, this defect caused losses due to scrap parts. The amount of scrap parts is 12 pcs and the amount of loss is Rp 1.637.569,in that period.The repair activity is using the Plan-Do-Check-Action (PDCA) method. According to result of problem causing analysis, it get several improvement implementations. There are adding WOS checking board, making Variant Checking Display, reducing buffer stock, making dolly placement identity, and dolly varian identity. From this repair activity, that defect can be reduced from 25 item to 0 item at May 2018 to June 2018 and the amount of scrap parts can be reduced from 12 pcs to 0 pcs. So that the loss due to scrap part becomes $R p$ 0,- and the target of management can be achieved.

Keywords : Quality, Defect, PDCA 


\section{PENDAHULUAN}

PT. XYZ adalah perusahaan yang bergerak di bidang manufaktur khususnya industri otomotif roda empat telah membuat banyak produk mobil, salah satunya unit mobil pick up D30N. Proses produksi unit D30N di PT. XYZ melalui beberapa departemen produksi, salah satunya yaitu Departemen Welding yang merupakan awal proses perakitan bodi mobil. Pada departemen ini, sub-sub part kecil digabungkan menjadi part ukuran sedang dan digabungkan menjadi sebuah unit bodi mobil. Proses penggabungan ini dilakukan dengan menggunakan metode pengelasan dan proses spot melalui beberapa stasiun kerja, diantaranya adalah Under Front, Under Body, Main Body, Shell Line, dan Metal Finish. Akan tetapi dalam proses produksi unit D30N di Departemen Welding, permasalahan kualitas menjadi hal yang sering muncul dan menjadi hambatan dalam mencapai target efisiensi produksi unit D30N. Target DPU (Defect Per Unit) dari manajemen untuk masalah keseluruhan kualitas pada produk unit D30N di dalam departemen Welding D30N adalah sebesar 0,02. Sedangkan pada produksi bulan September 2017 - Februari 2018, target DPU tidak memenuhi target. Berdasarkan data defect per jalur bulan September 2017 Februari 2018, jalur Under Front menjadi penyumbang defect terbanyak dengan 110 item. Dan defect yang paling besar pada jalur Under Front yaitu defect Salah Varian Panel Dash Join Front Floor sebanyak 25 item. Defect ini berdampak pada adanya part bracket Commuter scrap dan unit delay di jalur Under Front. Sehingga penelitian ini berfokus pada defect tersebut. Kegiatan pengendalian kualitas tersebut dilakukan dengan menggunakan metode pengendalian kualitas dengan menggunakan metode Plan-Do-Check-Action (PDCA). Identifikasi permasalahan dapat ditarik dari permasalahan ini adalah :

1. Apakah penyebab utama terjadinya defect Salah Varian Panel Dash Join Front Floor?

2. Perbaikan apa yang dilakukan untuk menanggulangi defect tersebut?

3. Apakah terjadi penurunan jumlah defect setelah dilakukan perbaikan pada defect tersebut?

Dari permasalahan tersebut dapat ditarik suatu tujuan dari penelitin ini adalah Mengetahui penyebab utama defect Salah Varian Panel Dash Join Front Floor, Memberikan solusi perbaikan terhadap defect Salah Varian Panel Dash Join Front Floor dan Mengetahui apakah terjadi penurunan jumlah defect setelah dilakukan perbaikan

\section{TINJAUAN PUSTAKA \\ Definisi Kualitas}

Pengertian atau definisi kualitas mempunyai cakupan yang sangat luas, relatif, berbeda-beda dan berubah-ubah, sehingga definisi dari kualitas memiliki banyak kriteria dan sangat bergantung pada konteksnya terutama jika dilihat dari sisi penilaian akhir konsumen dan definisi yang diberikan oleh berbagai ahli serta dari sudut pandang produsen sebagai pihak yang menciptakan kualitas. Konsumen dan produsen itu berbeda dan akan merasakan kualitas secara berbeda pula sesuai dengan standar kualitas yang dimiliki masing-masing. Begitu pula para ahli dalam memberikan definisi dari kualitas juga akan berbeda satu sama lain karena mereka membentuknya dalam dimensi yang berbeda. Adapun pengertian kualitas dalam ISO 8402 (Quality Vocabulary), kualitas didefinisikan sebagai totalitas dari karakteristik suatu produk yang menunjang kemampuannya untk memuaskan kebutuhan yang dispesifikasikan atau ditetapkan. Kualitas seringkali diartikan sebagai kepuasan pelanggan (customer satisfaction) atau konformansi terhadap kebtuhan atau persyaratan (Vincent Gasperz, 2014, h.5)

\section{Dimensi Kualitas}

Dimensi kualitas menurut Garvin (dalam Gazperz, 1997:.3) sebagaimana ditulis oleh Fandy Tjiptono dan Anastasia Diana (2014, h.27) dalam bukunya, mengidentifikasikan delapan dimensi kualitas yang dapat digunakan sebagai kerangka perencanaan strategis dan analisis, terutama untuk produk manufaktur. Dimensi-dimensi tersebut adalah:

1. Performa (performance),

2. Keistimewaan (features

3. Keandalan (reliability

4. Konformansi (conformance),

5. Daya tahan (durability,

6. Kemampuan pelayanan (service ability),

7. Estetika (aesthetics),

8. Kualitas yang dipersepsikan (perceived quality). 


\section{Penyebab Masalah Kualitas}

Sumber penyebab masalah kualitas yang ditemukan berdasarkan prinsip 7M, yaitu: (Gaspersz, 2011)

1. Manpower (tenaga kerja),

2. Machines (mesin dan peralatan),

3. Methods (metode kerja),

4. Materials (bahan baku),

5. Media/Environment,

6. Motivation (motivasi),

7. Money (keuangan).

\section{Total Quality Management (TQM)}

Penerapan sistem Manajemen Mutu dalam berorganisasi dan semangat yang melatarbelakangi hadirnya perubahan oleh organisasi dalam memandang penting dan perlunya menegakkan prinsip kualitas tidak dapat dipisahkan dari Total Quality Management. TQM merupakan seni dalam mengelola segala sumber daya yang ada untuk mencapai tujuan organisasi. Pola manajemn industri sebelum TQM lahir adalah berorientasi pada produk yang dihasilkan, sedangkan TQM lebih menekankan terhadap konsumen dan pelanggan.Definisi TQM merupakan suatu pendekatan dalam menjalankan usaha yang mencoba untuk memaksimumkan daya saing organisasi melalui perbaikan terus menerus atas produk, jasa, tenaga kerja, proses, dan lingkungannya. (Vincent Gasperz, 2014, h.17).

\section{PDCA (Plan, Do, Check, Action)}

Siklus PDCA atau siklus Deming ini dikembangkan untuk menghubungkan antara operasi dengan kebutuhan pelanggan dan memfokuskan sumber daya semua bagian dalam perusahaan (riset, desain operasi, dan pemasaran) secara terpadu dan sinergi untuk memenuhi kebutuhan pelanggan (Ross, 1994:237). Siklus Deming adalah model perbaikan berkesinambungan yang dikembangkan oleh W. Edward Deming yang terdiri atas 4 komponen utama secara berurutan yaitu:. (M. N. Nasution, 2015, h.26).

1. Mengembangkan rencana (Plan)

Merencanakan spesifikasi, menetapkan spesifikasi atau standar kualitas yang baik, memberi pengertian kepada bawahan akan pentingnya kualitas produk, pengendalian kualitas dilakukan secara terus-menerus dan berkesinambungan.

2. Melaksanakan rencana $(D o)$
Rencana yang telah disusun diimplementasikan secara bertahap, mulai dari skala kecil dan pembagian tugas secara merata sesuai dengan kapasitas dan kemampuan dari setiap personil. Selama dalam melaksanakan rencana harus dilakukan pengendalian, yaitu mengupayakan agar seluruh rencana dilaksanakan dengan sebaik mungkin agar sasaran dapat tercapai.

3. Memeriksa atau meneliti hasil yang dicapai (Check)

Memeriksa atau meneliti merujuk pada penetapan apakah pelaksanaannya berada dalam jalur, sesuai dengan rencana dan memantau kemajuan perbaikan yang direncanakan. Membandingkan kualitas hasil produksi dengan standar yang telah ditetapkan, berdasarkan penelitian diperoleh data kegagalan dan kemudian ditelaah penyebab kegagalannya.

4. Melakukan tindakan penyesuaian bila diperlukan (Action)

Penyesuaian dilakukan bila dianggap perlu, yang didasarkan hasil analisis di atas. Penyesuaian berkaitan dengan standarisasi prosedur baru guna menghindari timbulnya kembali masalah yang sama atau menetapkan sasaran baru bagi perbaikan berikutnya.

\section{Alat Bantu Dalam PDCA}

Setiap metode perbaikan kualitas tentu ditunjang oleh alat-alat bantu yang disebut "Alat-Alat Kualitas" atau "Quality Tools". Quality tools memiliki fungsi untuk membantu dan mempermudah dalam menginterpretasi masalah seputar kualitas ke dalam tampilan visual baik tabel maupun grafis. Penggunaan tools yang tepat sasaran tentunya akan memberikan hasil yang lebih optimal. Berikut adalah alat-alat yang biasa digunakan dalam perbaikan kualitas dalam menggunakan metode PDCA. (Hendy Tannady, 2014, h.35).

1. Lembar Pemeriksaan (Checksheet)

2. Diagram Pareto

3. Diagram Alir

4. Diagram Sebab Akibat

5. Analisis $5 \mathrm{~W} 1 \mathrm{H}$ 


\section{METODE PENELITIAN}

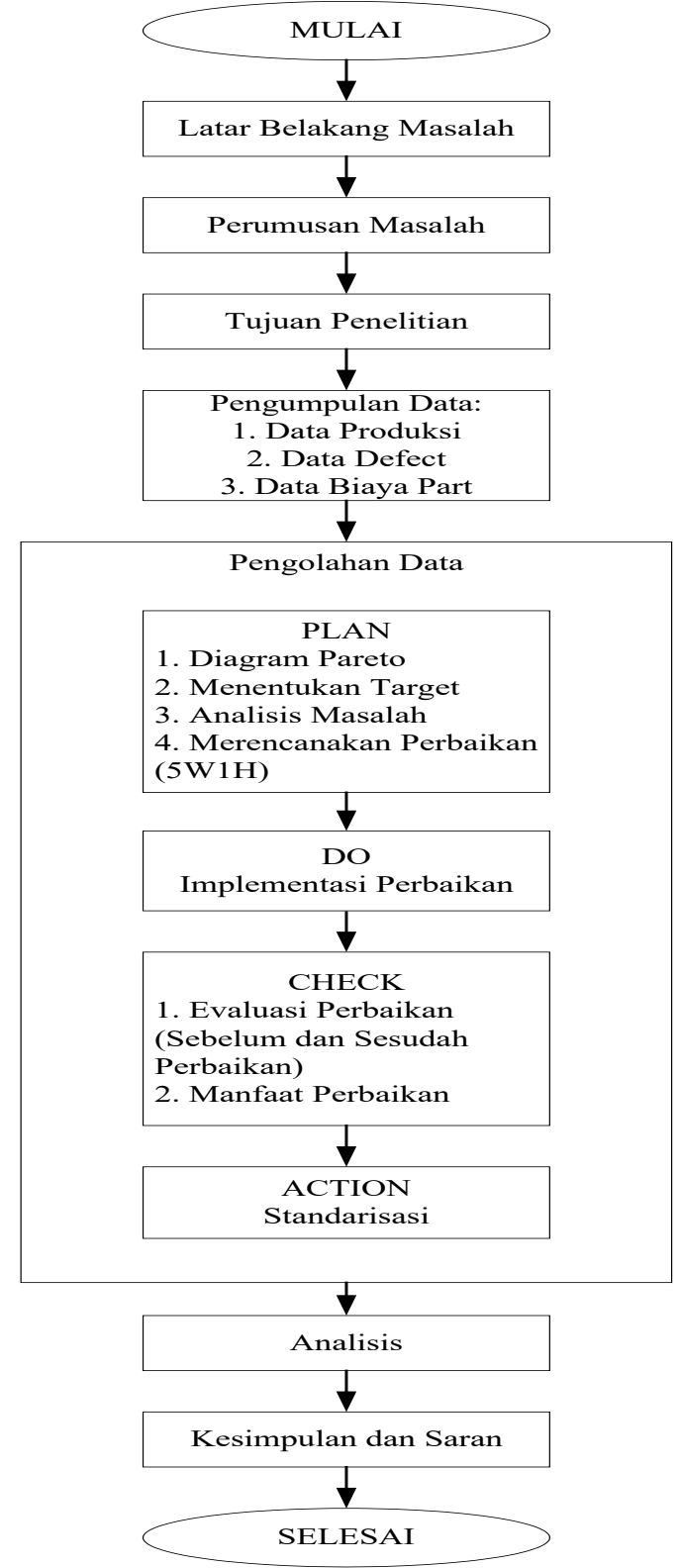

Gambar 3.1 Metodologi Penelitian

\section{HASIL DAN PEMBAHASAN}

\subsection{Pengumpulan Data}

1. Jumlah Produksi dan Jumlah Defect

Tabel 4.1 Tabel Data Jumlah Defect

Departemen Welding D30N

\begin{tabular}{|c|c|c|c|c|c|}
\hline No. & Bulan & Jumlah Unit & Jumlah Defect & DPU & Target DPU \\
\hline 1 & Sep-17 & 685 & 36 & 0,053 & \multirow{6}{*}{0,02} \\
\hline 2 & Okt-17 & 670 & 37 & 0,055 & \\
\hline 3 & Nov-17 & 680 & 31 & 0,046 & \\
\hline 4 & Des-17 & 680 & 34 & 0,050 & \\
\hline 5 & Jan-18 & 670 & 33 & 0,049 & \\
\hline 6 & Feb-18 & 685 & 30 & 0,044 & \\
\hline \multicolumn{2}{|c|}{ TOTAL } & 4070 & 201 & & \\
\hline
\end{tabular}

(Sumber Data: Perusahaan)
Berdasarkan tabel diatas, diketahui bahwa jumlah DPU yang dicapai selama 6 bulan tidak mencapai target yang ditetapkan manajemen. Hal ini menunjukkan terdapat permasalahan kualitas yang terjadi di departemen Welding D30N. Berikut ini adalah data jumlah defect di jalur produksi di Departemen Welding D30N.

Tabel 4.2 Tabel Data Jumlah Defect Per Jalur di Departemen Welding D30N

\begin{tabular}{|c|c|c|c|c|c|c|c|c|}
\hline \multirow{2}{*}{\begin{tabular}{|c|} 
JALUR \\
PRODUKSI
\end{tabular}} & \multirow{2}{*}{ DEFECT } & \multicolumn{6}{|c|}{ Bulan } & \multirow{2}{*}{$\begin{array}{l}\text { TOTAL } \\
\text { DEFECI }\end{array}$} \\
\hline & & Sep-17 & Okt-17 & Nov-17 & Des-17 & Jan-18 & Feb-18 & \\
\hline \multirow{5}{*}{ Under Front } & Salah Varian Panel Dash Join Front Floor & 5 & 4 & 3 & 5 & 4 & 4 & 25 \\
\hline & Plat Tidak Rata Area Panel Dash & 5 & 5 & 4 & 3 & 3 & 4 & 24 \\
\hline & Spatter Area Front Floor & 3 & 4 & 2 & 4 & 5 & 5 & 23 \\
\hline & Gompal Area Front Floor & 5 & 5 & 3 & 3 & 4 & 2 & 22 \\
\hline & Stud Bolt Panel Dash Tidak Terpasang & 3 & 3 & 2 & 2 & 4 & 2 & 16 \\
\hline \multirow{3}{*}{ Under Body } & Spatter Area Panel Back & 1 & 2 & 2 & 1 & 1 & 1 & 8 \\
\hline & Panel Back Pecok & 1 & 2 & 1 & 1 & 2 & 0 & 7 \\
\hline & Spatter Area Sub Assy Under Body & 2 & 3 & 2 & 1 & 1 & 2 & 11 \\
\hline \multirow{4}{*}{ Main Body } & Windshield Benjol & 2 & 2 & 3 & 1 & 1 & 1 & 10 \\
\hline & Spatter Area Center Pillar & 0 & 0 & 2 & 2 & 1 & 2 & 7 \\
\hline & Roof Benjol & 0 & 1 & 1 & 1 & 0 & 1 & 4 \\
\hline & Rear Body Benjol & 1 & 1 & 0 & 1 & 0 & 0 & 3 \\
\hline \multirow{3}{*}{ Shell Line } & Front Door Outer Benjol & 3 & 2 & 1 & 2 & 2 & 1 & 11 \\
\hline & Gap Front Door Join Center Pillar Sempit & 1 & 1 & 0 & 2 & 0 & 1 & 5 \\
\hline & Front Door (x) Front Pillar Jogle & 1 & 0 & 1 & 1 & 0 & 2 & 5 \\
\hline \multirow{4}{*}{ Metal Finish } & Pillar Pecok & 0 & 0 & 1 & 1 & 1 & 1 & 4 \\
\hline & Karat Area Panel Dash & 1 & 2 & 1 & 2 & 1 & 0 & 7 \\
\hline & Side Gate Gompal & 2 & 0 & 2 & 1 & 3 & 1 & 9 \\
\hline & TOTAL DEFFECT & 36 & 37 & 31 & 34 & 33 & 30 & 201 \\
\hline
\end{tabular}

(Sumber Data: Perusahaan)

Berdasarkan data tersebut defect Salah Varian Panel Dash Join Front Floor merupakan defect terbesar.

2. Dampak Defect

Berikut adalah dampak tersebut defect Salah Varian Panel Dash Join Front Floor.

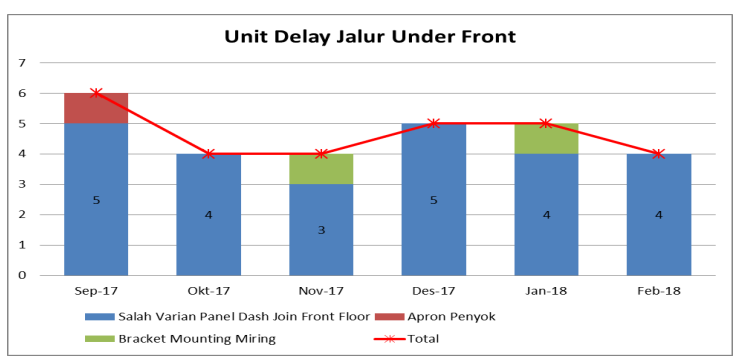

Gambar 4.1 Unit Delay Jalur Under Front

Berdasarkan data diatas, defect Salah Varian Panel Dash Join Front Floor memiliki jumlah delay sebesar 25 unit dari periode September 2017 sampai dengan Februari 2018. Dampak lain dari defect tersebut yaitu adanya part Bracket Commuter yang scrap dengan data sebagai berikut. 


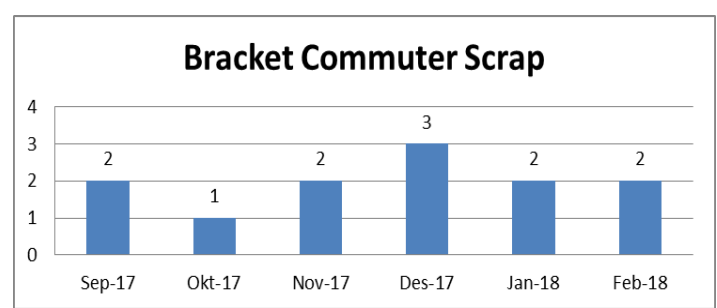

Gambar 4.2 Grafik Bracket Commuter Scrap

Berdasarkan grafik tersebut, jumlah part Bracket Commuter yang dari periode September 2017 sampai dengan Februari 2018 sebesar 12 unit. Berikut adalah besar nominal yang diterima akibat part Bracket Commuter yang scrap.

Tabel 4.3 Jumlah Kerugian Akibat Bracket

\begin{tabular}{|c|c|c|c|c|}
\multicolumn{5}{|c}{ Commuter Scrap } \\
\hline Material & $\begin{array}{c}\text { Material } \\
\text { Description }\end{array}$ & Harga & $\begin{array}{c}\text { Jumlah } \\
\text { Scrap }\end{array}$ & $\begin{array}{c}\text { Total Harga } \\
\text { Scrap }\end{array}$ \\
\hline $\begin{array}{c}58127- \\
\text { BZ040 }\end{array}$ & $\begin{array}{c}\text { Bracket } \\
\text { Commuter }\end{array}$ & 136464 & 12 & 1637568 \\
\hline
\end{tabular}

(Sumber Data Perusahaan)

\section{Proses Setting Panel Dash Join Front} Floor.

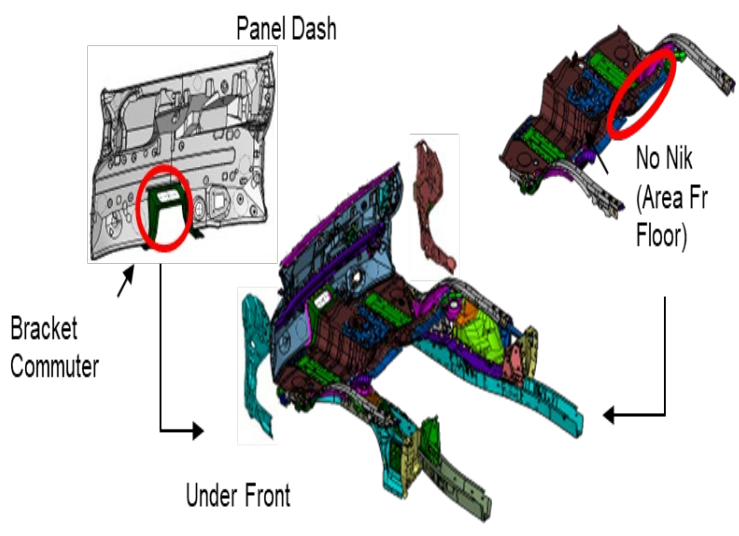

Gambar 4.3 Proses Setting Panel Dash Join Front Floor

Saat proses pemasangan Panel Dash Join Front Floor, operator harus menyesuaikan antara barcode dengan kode NIK (Nomor Induk Kendaraan) pada Front Floor dan varian tipe Panel Dash. Berikut ini adalah part yang membedakan tipe Panel Dash menjadi 2, yaitu kode YD dan $\mathrm{BH}$.
Tabel 4.4 Perbedaan Variant Panel Dash

\begin{tabular}{|c|c|c|}
\hline \multirow{2}{*}{ Part } & \multicolumn{2}{|c|}{ Varian Panel Dash } \\
\cline { 2 - 3 } & YD & Barian \\
\hline \multirow{3}{*}{$\begin{array}{c}\text { Bracket } \\
\text { Commuter }\end{array}$} & & \\
& & \\
\hline
\end{tabular}

(Sumber Data: Perusahaan)

Kondisi aktual dari defect Salah Varian Panel Dash Join Front Floor adalah saat sudah terpasang, varian Panel Dash tidak sesuai dengan kode NIK pada Front Floor.

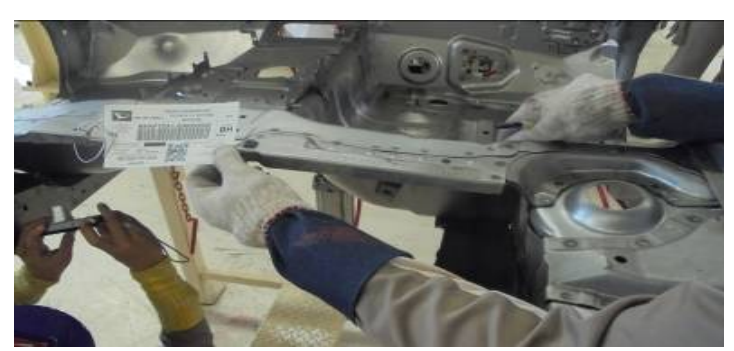

Gambar 4.4 Kondisi Aktual Unit

\subsection{Pengolahan Data}

\subsubsection{Perencanaan (PLAN)}

1. Identifikasi Masalah

Penelitian masalah dalam tugas akhir ini dilakukan di PT. XYZ di Departemen Welding D30N. Penelitian ini membahas masalah kualitas dimana untuk permasalahan kualitas ini tidak mencapai target yang ditetapkan manajemen. Berikut adalah data jumlah defect di dalam Departemen Welding D30N dari bulan September 2017 - Februari 2018.

Tabel 4.9 Tabel Data Jumlah Defect Departemen Welding D30N

\begin{tabular}{|c|c|c|c|c|c|}
\hline No. & Bulan & Jumlah Unit & Jumlah Defect & DPU & Target DPU \\
\hline 1 & Sep-17 & 685 & 36 & 0,053 & \multirow{6}{*}{0,02} \\
\hline 2 & 0kt-17 & 670 & 37 & 0,055 & \\
\hline 3 & Nov-17 & 680 & 31 & 0,046 & \\
\hline 4 & Des-17 & 680 & 34 & 0,050 & \\
\hline 5 & Jan-18 & 670 & 33 & 0,049 & \\
\hline 6 & Feb-18 & 685 & 30 & 0,044 & \\
\hline \multicolumn{2}{|c|}{ TOTAL } & 4070 & 201 & & \\
\hline
\end{tabular}

(Sumber Data: Perusahaan)

Data diatas menunjukkan DPU dari Departemen Welding D30N tidak mencapai target. Kemudian permasalahan ini di analisis 
dengan melihat pada jumlah defect per jalur, dimana manajemen menetapkan target untuk masing masing jalur sebesar 0,004. Berikut adalah data jumlah defect per jalur tersebut.

Tabel 4.10 Tabel Data Jumlah Defect Per Jalur di Departemen Welding D30N

\begin{tabular}{|c|c|c|c|c|c|c|c|c|c|}
\hline \multirow{2}{*}{$\begin{array}{c}\text { JALUR } \\
\text { PRODUKSI }\end{array}$} & \multicolumn{6}{|c|}{ Bulan } & \multirow{2}{*}{$\begin{array}{l}\text { TOTAL } \\
\text { DEFECT }\end{array}$} & \multirow{2}{*}{ DPU } & \multirow{2}{*}{$\begin{array}{c}\text { TARGET } \\
\text { DPUPER } \\
\text { JALUR }\end{array}$} \\
\hline & Sep-17 & 0kt-17 & Nov-17 & Des-17 & Jan-18 & Feb-18 & & & \\
\hline Under Front & 21 & 21 & 14 & 17 & 20 & 17 & 110 & 0,027 & 0,004 \\
\hline Under Body & 4 & 7 & 5 & 3 & 4 & 3 & 26 & 0,006 & 0,004 \\
\hline Main Body & 3 & 4 & 6 & 5 & 2 & 4 & 24 & 0,006 & 0,004 \\
\hline Shell Line & 5 & 3 & 2 & 5 & 2 & 4 & 21 & 0,005 & 0,004 \\
\hline Metal Finish & 3 & 2 & 4 & 4 & 5 & 2 & 20 & 0,005 & 0,004 \\
\hline TOTAL & 36 & 37 & 31 & 34 & 33 & 30 & 201 & & \\
\hline
\end{tabular}

(Sumber Data: Perusahaan)

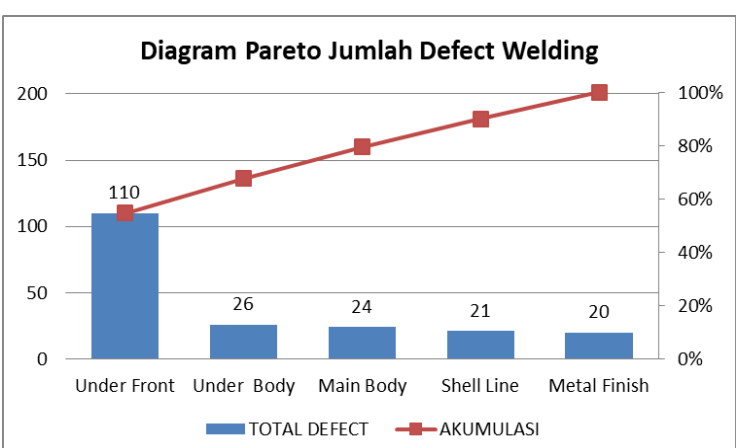

Gambar 4.4 Diagram Pareto Jumlah Defect Welding

Dari data diatas menunjukkan bahwa jalur Under Front memiliki jumlah defect terbesar. Kemudian analisis dilanjutkan dengan melihat defect yang muncul di jalur Under Front. Berikut adalah data defect di jalur Under Front.

Tabel 4.11 Tabel Data Defect di Jalur Under Front

\begin{tabular}{|l|c|c|c|c|c|c|c|c|}
\hline \multirow{2}{*}{ DEFECT } & \multicolumn{5}{|c|}{ Bulan } & TOTAL & KATEGORI \\
\cline { 2 - 9 } & Sep-17 & 0kt-17 & Nov-17 & Des-17 & Jan-18 & Feb-18 & DEFECT & DEFECT \\
\hline Salah Varian Panel Dash Join Front Floor & 5 & 4 & 3 & 5 & 4 & 4 & 25 & FUNCTION \\
\hline Plat Tidak Rata Area Panel Dash & 5 & 5 & 4 & 3 & 3 & 4 & 24 & APPEARANCE \\
\hline Spatter Area Front Floor & 3 & 4 & 2 & 4 & 5 & 5 & 23 & FUNCTION \\
\hline Gompal Area Front Floor & 5 & 5 & 3 & 3 & 4 & 2 & 22 & APPEARANCE \\
\hline Stud Bolt Panel Dash Tidak Terpasang & 3 & 3 & 2 & 2 & 4 & 2 & 16 & FUNCTION \\
\hline TOTAL DEFFECT & 21 & 21 & 14 & 17 & 20 & 17 & 110 & \\
\hline
\end{tabular}

(Sumber Data: Perusahaan)
Dari data diatas dapat disimpulkan bahwa defect Salah Varian Panel Dash Join Front Floor merupakan yang paling besar. Selain itu, defect Salah Varian Panel Dash Join Front Floor memiliki dampak dengan adanya unit delay dan adanya scrap part, sehingga penelitian ini akan berfokus pada defect tersebut.

\section{Menentukan Target}

Penetapan target dengan menggunakan metode SMART sebagai berikut.

1) Specific

Menanggulangi defect Salah Varian Panel Dash Join Front Floor.

2) Measurable

Menurunkan defect tersebut dari 25 menjadi 0 atau sesuai dengan target manajemen untuk defect function.

3) Attainable

Target dapat dicapai dengan banyaknya potensi perbaikan.

4) Realistic

Target sesuai dengan ketetapan manajemen untuk garansi kualitas tiap jalur.

5) Time lines

Target penyelesaian masalah adalah 2 bulan.

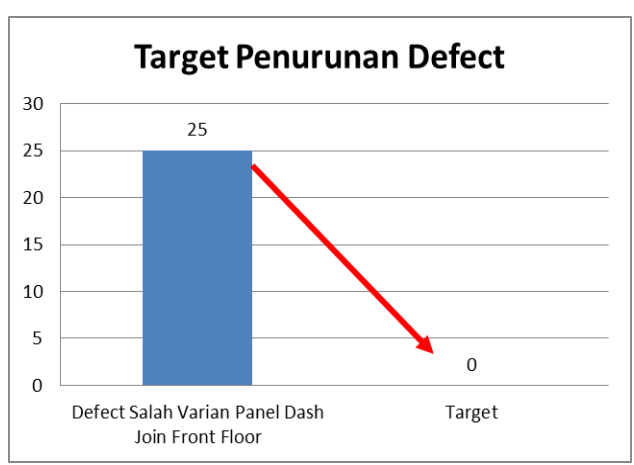

Gambar 4.4 Grafik Target Penurunan Defect

3. Analisis Penyebab Masalah

Analisis dilakukan dengan brainstorming bersama beberapa karyawan yang tergabung dalam kelompok QCC (Quality Control Circle) yang berjumlah 6 orang anggota dan 1 orang Leader. Berikut ini adalah hasil brainstroming. 
Tabel 4.5 Hasil Brainstorming

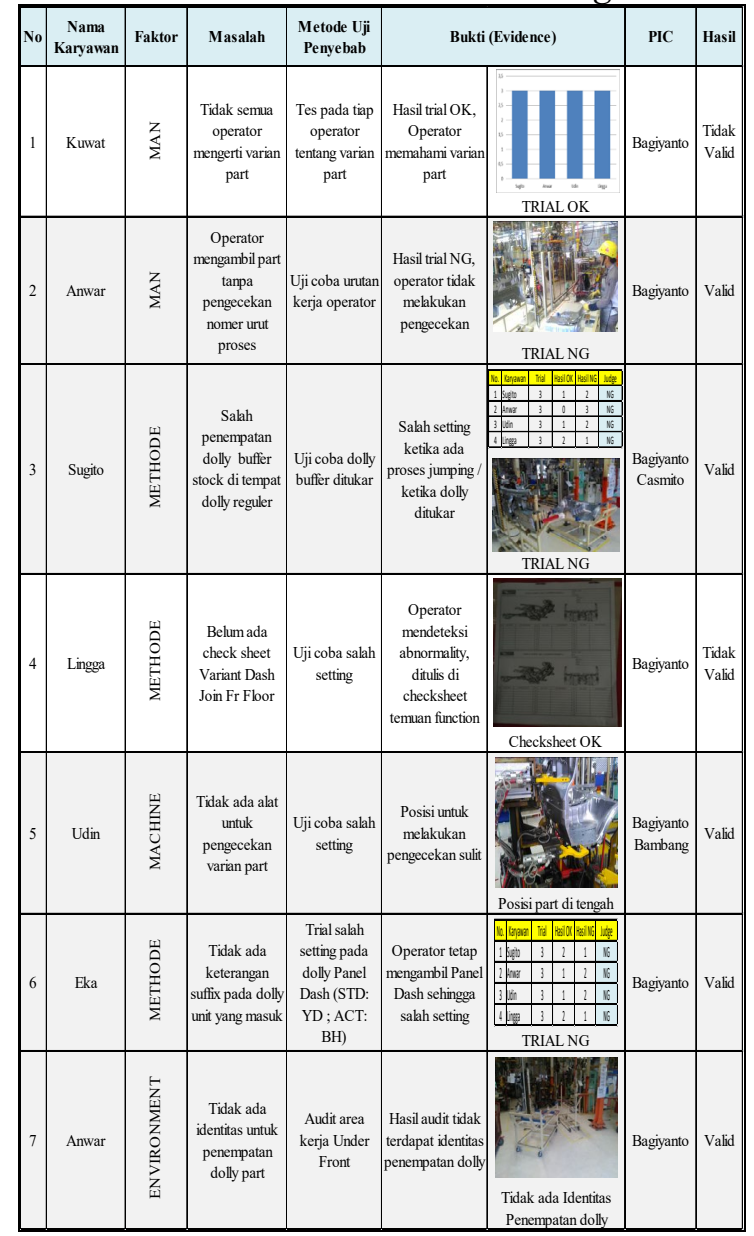

(Sumber Data: Hasil Pengamatan)

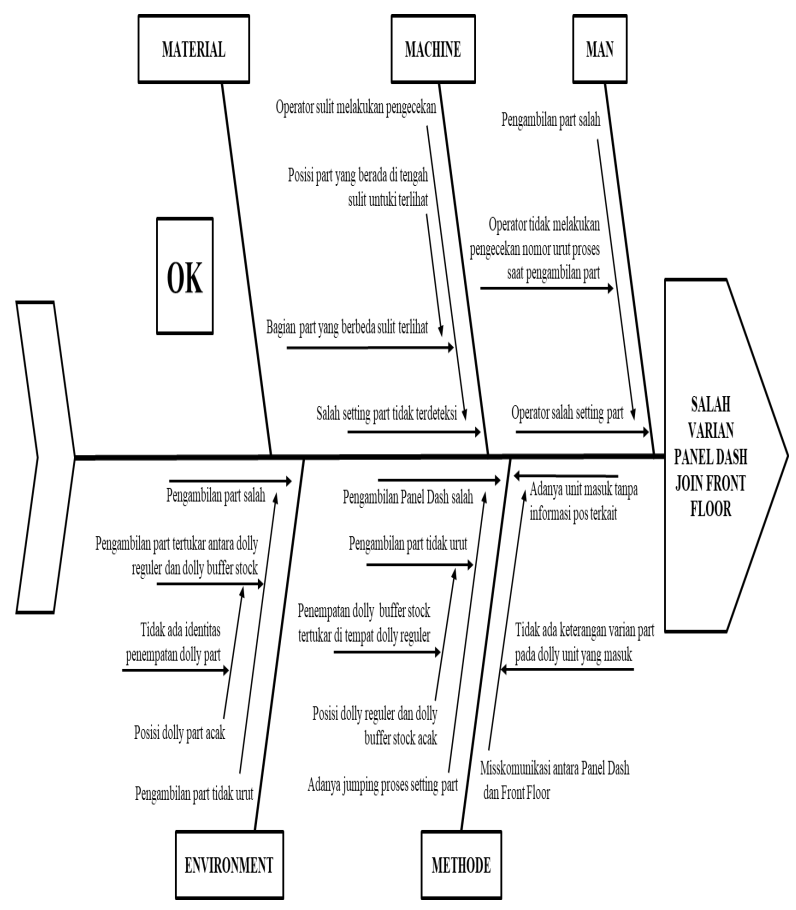

Gambar 4.5 Diagram Fisbone
4. Merencanakan Perbaikan

Tabel 4.6 Rencana Perbaikan 5W-1H

\begin{tabular}{|c|c|c|c|c|c|c|}
\hline No & What & Why & Where & Who & When & How \\
\hline 1 & \begin{tabular}{|c|} 
Operator tidak \\
melakukan \\
pengecekan nomer \\
urut proses saat \\
mengambil part
\end{tabular} & $\begin{array}{c}\text { Agar saat } \\
\text { pengambilan part } \\
\text { sesuai dengan } \\
\text { nomor Work } \\
\text { Order Sheet }\end{array}$ & $\begin{array}{l}\text { Under } \\
\text { Front }\end{array}$ & Sugito & Apr-18 & $\begin{array}{c}\text { Membuat papan } \\
\text { pengecekan } \\
\text { Work Order } \\
\text { Sheet }\end{array}$ \\
\hline 2 & $\begin{array}{c}\text { Penempatan dolly } \\
\text { buffer stock } \\
\text { tertukar di tempat } \\
\text { dolly reguler }\end{array}$ & $\begin{array}{l}\text { Agar tidak terjadi } \\
\text { jumping proses } \\
\text { setting Panel Dash }\end{array}$ & $\begin{array}{c}\text { S/A Dash } \\
\text { Under } \\
\text { Front }\end{array}$ & $\begin{array}{l}\text { Anwar \& } \\
\text { Bagiyanto }\end{array}$ & Apr-18 & $\begin{array}{l}\text { Mengurangi } \\
\text { buffer stock }\end{array}$ \\
\hline 3 & $\begin{array}{c}\text { Tidak ada } \\
\text { keterangan varian } \\
\text { pada dolly unit yang } \\
\text { masuk }\end{array}$ & $\begin{array}{c}\text { Agar varian unit } \\
\text { yang masuk dapat } \\
\text { diketahui operator } \\
\text { dan tidak terjadi } \\
\text { misskomunikasi }\end{array}$ & $\begin{array}{l}\text { Under } \\
\text { Front }\end{array}$ & Sugito & Apr-18 & $\begin{array}{l}\text { Membuat papan } \\
\text { keterangan pada } \\
\text { dolly Panel Dash }\end{array}$ \\
\hline 4 & $\begin{array}{c}\text { Bagian part yang } \\
\text { berbeda sulit } \\
\text { terlihat }\end{array}$ & $\begin{array}{c}\text { Agar proses } \\
\text { pengecekan varian } \\
\text { Panel Dash lebih } \\
\text { mudah }\end{array}$ & $\begin{array}{l}\text { Under } \\
\text { Front }\end{array}$ & $\begin{array}{c}\text { Anwar, } \\
\text { Sugito, \& } \\
\text { Bagiyanto }\end{array}$ & Apr-18 & \begin{tabular}{|c|} 
Dibuatkan \\
display \\
pengecekan \\
varian pada jig \\
setting Panel \\
Dash \\
\end{tabular} \\
\hline 5 & $\begin{array}{c}\text { Tidak ada identitas } \\
\text { untuk penempatan } \\
\text { dolly part }\end{array}$ & $\begin{array}{c}\text { Agar penempatan } \\
\text { dolly lebih rapih dan } \\
\text { sesuai urutan } \\
\text { proses }\end{array}$ & $\begin{array}{l}\text { Under } \\
\text { Front }\end{array}$ & Anwar & Apr-18 & \begin{tabular}{|c|} 
Membuat \\
identitas untuk \\
penempatan \\
dolly part
\end{tabular} \\
\hline
\end{tabular}

(Sumber data: Hasil Pengamatan)

\subsubsection{Implementasi Perbaikan (DO)}

Tabel 4.7 Tabel Metode 5W - 1H Untuk Akar Penyebab 1

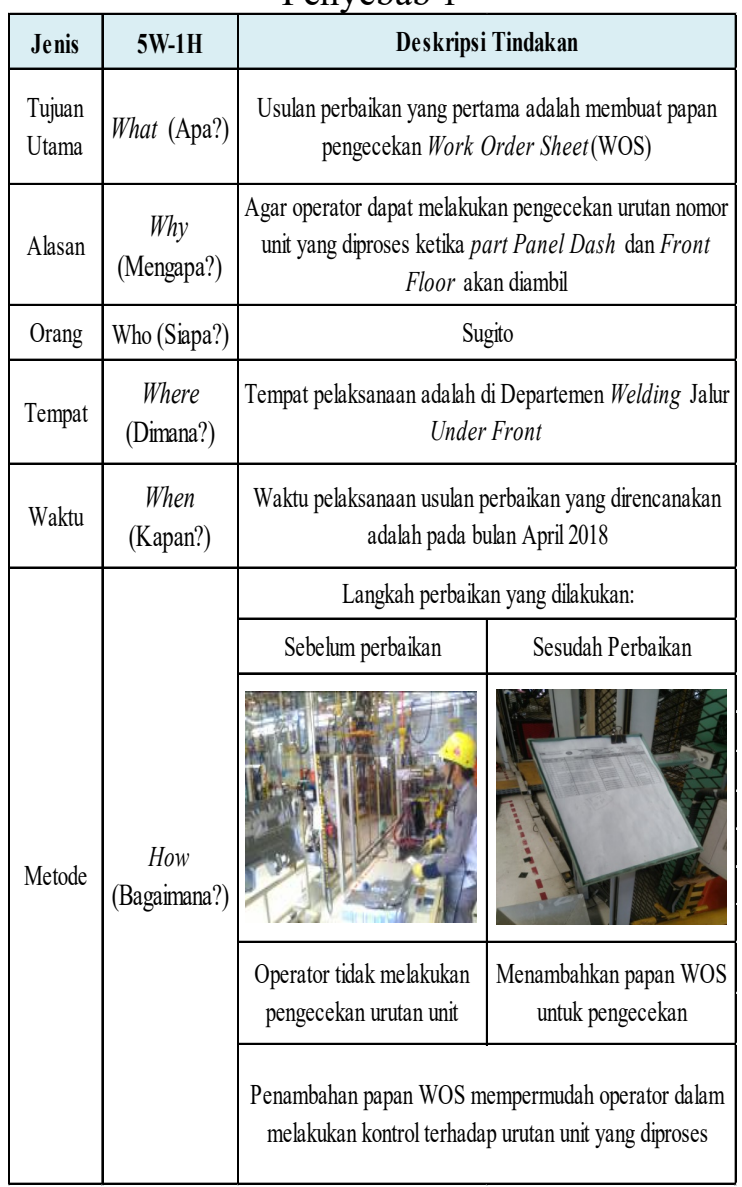

(Sumber data: Hasil Penelitian) 
Tabel 4.8 Tabel Metode 5W - 1H Untuk Akar Penyebab 2

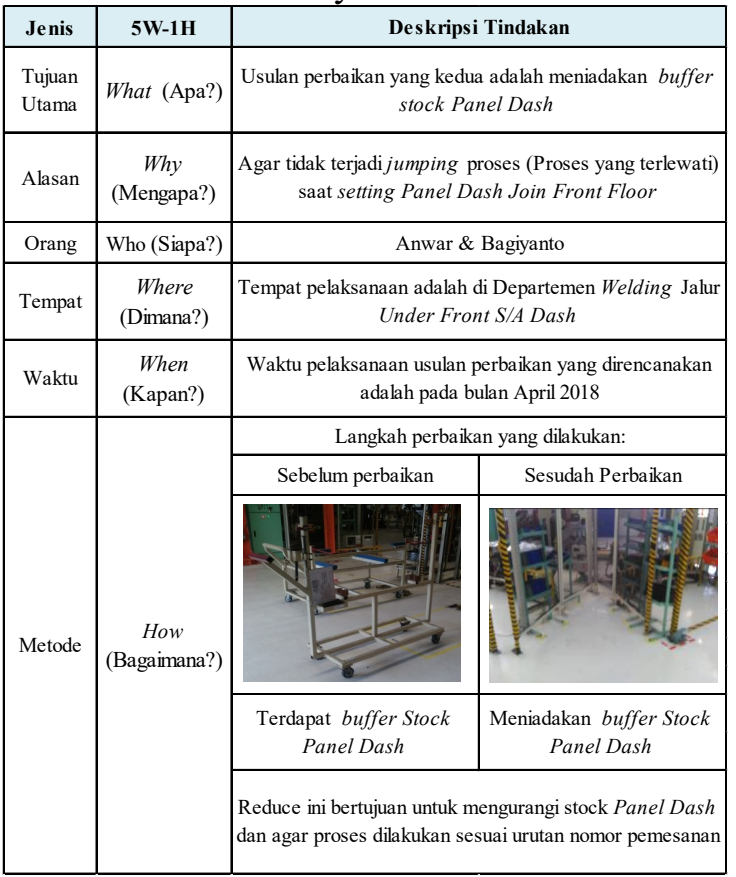

\section{(Sumber data: Hasil Penelitian)}

Tabel 4.9 Tabel Metode 5W - 1H Untuk Akar Penyebab 3

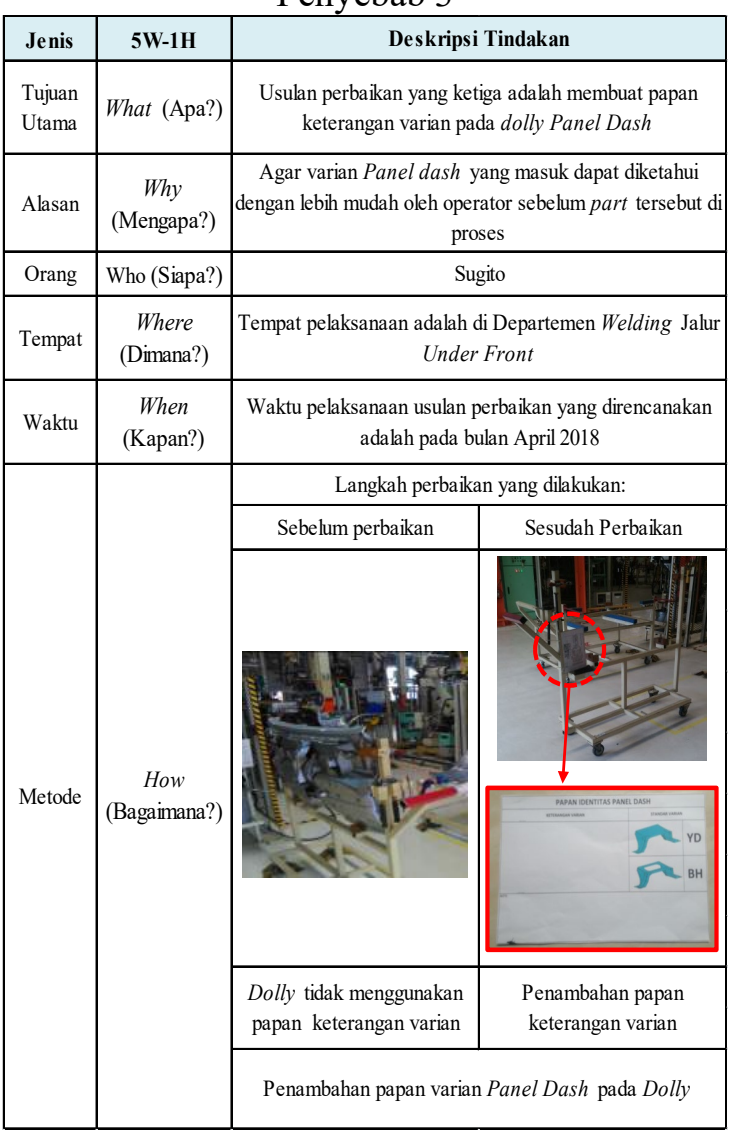

(Sumber data: Hasil Penelitian)
Tabel 4.10 Tabel Metode 5W - 1H Untuk Akar Penyebab 4

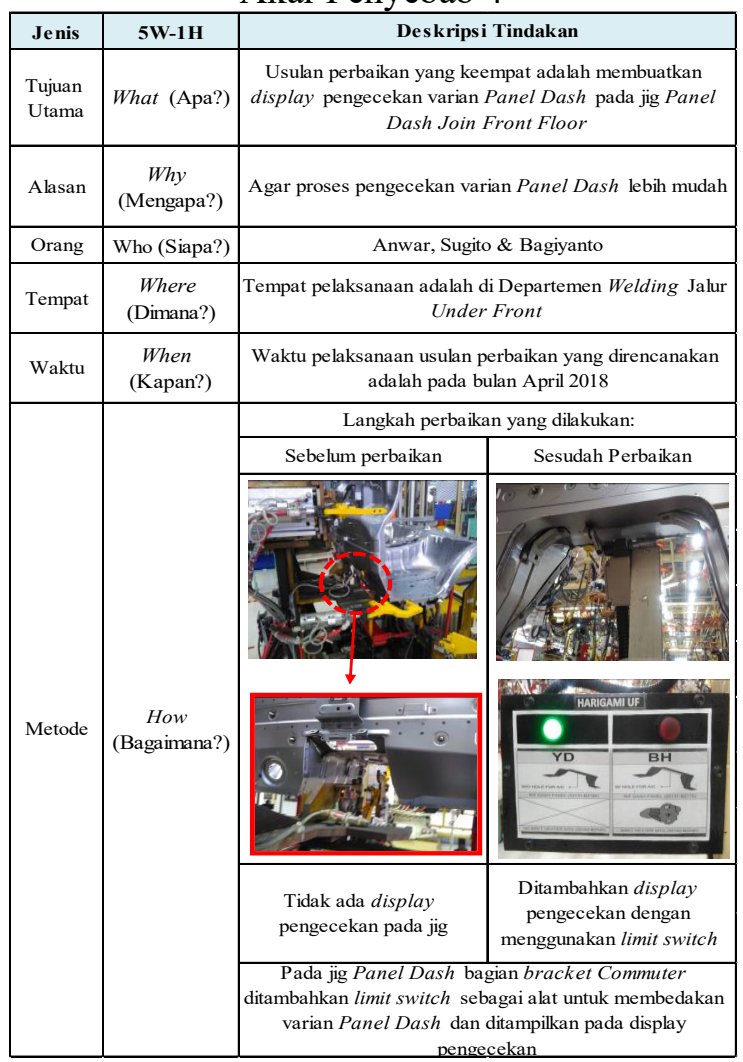

(Sumber data: Hasil Penelitian)

Tabel 4.11 Tabel Metode 5W - 1H Untuk Akar Penyebab 5

\begin{tabular}{|c|c|c|c|}
\hline Jenis & $5 \mathrm{~W}-1 \mathrm{H}$ & \multicolumn{2}{|c|}{ Deskripsi Tindakan } \\
\hline $\begin{array}{l}\text { Tujuan } \\
\text { Utama }\end{array}$ & What (Apa?) & \multicolumn{2}{|c|}{$\begin{array}{l}\text { Usulan perbaikan yang kelima adalah membuat identitas } \\
\text { untuk penempatan dolly Panel Dash dan Front Floor }\end{array}$} \\
\hline Alasan & $\begin{array}{c}\text { Why } \\
\text { (Mengapa?) }\end{array}$ & \multicolumn{2}{|c|}{$\begin{array}{l}\text { Agar penempatan part lebih rapih dan sesuai urutan unit } \\
\text { yang diproses sehingga operator tidak asal mengambil part }\end{array}$} \\
\hline Orang & Who (Siapa?) & \multicolumn{2}{|c|}{ Anwar } \\
\hline Tempat & $\begin{array}{l}\text { Where } \\
\text { (Dimana?) }\end{array}$ & \multicolumn{2}{|c|}{$\begin{array}{l}\text { Tempat pelaksanaan adalah di Departemen Welding Jalur } \\
\text { Under Front }\end{array}$} \\
\hline Waktu & $\begin{array}{c}\text { When } \\
\text { (Kapan?) }\end{array}$ & \multicolumn{2}{|c|}{$\begin{array}{l}\text { Waktu pelaksanaan usulan perbaikan yang direncanakan } \\
\text { adalah pada bulan April } 2018\end{array}$} \\
\hline \multirow{5}{*}{ Metode } & \multirow{5}{*}{$\begin{array}{c}\text { How } \\
\text { (Bagaimana?) }\end{array}$} & \multicolumn{2}{|c|}{ Langkah perbaikan yang dilakukan: } \\
\hline & & Sebelum perbaikan & Sesudah Perbaikan \\
\hline & & & die \\
\hline & & $\begin{array}{l}\text { Penempatan dolly part } \\
\text { berantakan }\end{array}$ & $\begin{array}{l}\text { Penambahan identitas } \\
\text { penempatan dolly part }\end{array}$ \\
\hline & & $\begin{array}{r}\text { Identitas dibuat untuk pen } \\
\text { yang }\end{array}$ & $\begin{array}{l}\tan \text { part sesuai urutan unit } \\
\text { oses }\end{array}$ \\
\hline
\end{tabular}

(Sumber data: Hasil Penelitian) 


\subsubsection{Evaluasi Aktivitas Perbaikan (CHECK)}

Evaluasi perbaikan dilakukan ketika aktivitas implementasi perbaikan telah selesai dilakukan, dengan membandingkan data defect, data unit delay, dan data jumlah part Bracket Commuter scrap yang terjadi sebelum perbaikan yaitu pada September 2017 Februari 2018 dan data sesudah implementasi perbaikan yaitu pada bulan Maret 2018 - Juni 2018Berikut adalah hasil evaluasi defect, unit delay dan part scrap sebelum dan sesudah perbaikan.

Tabel 4.19 Tabel Evaluasi Sebelum dan Sesudah Perbaikan

\begin{tabular}{|c|c|c|c|}
\hline & Sebelum Perbaikan & \multicolumn{2}{|c|}{ Sesudah Perbaikan } \\
\hline Bulan & Sept 2017 - Feb 2018 & Mei-18 & Jun-18 \\
\hline Jumlah Defect & 25 & 0 & 0 \\
\hline $\begin{array}{c}\text { Jumlah Unit } \\
\text { Delay }\end{array}$ & 25 & 0 & 0 \\
\hline $\begin{array}{c}\text { Jumlah Bracket } \\
\text { Commuter Scrap }\end{array}$ & 12 & 0 & 0 \\
\hline $\begin{array}{c}\text { Jumlah Biaya } \\
\text { Scap }\end{array}$ & Rp1.637.568 & 0 & 0 \\
\hline
\end{tabular}

(Sumber Data: Perusahaan)

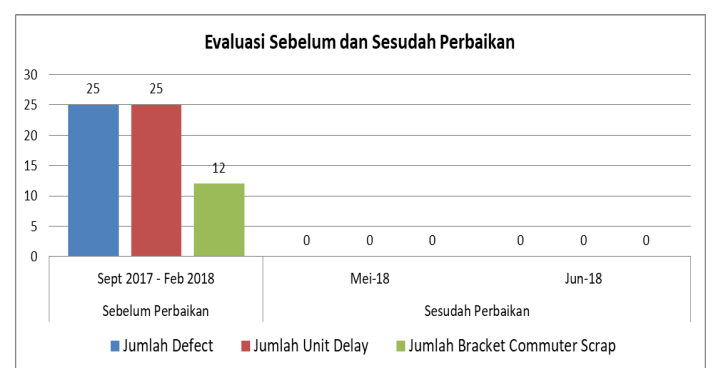

Gambar 4.18 Grafik Evaluasi Sebelum dan Sesudah Perbaikan

Dari aktifitas perbaikan tersebut, diperoleh beberapa manfaat yaitu sebagai berikut.

1. Jumlah defect Salah Varian Panel Dash Join Front Floor menjadi 0 sesuai dengan target manajemen untuk defect function.

2. Jumlah part Bracket Commuter yang scrap menjadi 0 .

3. Mengurangi jumlah unit tunda di Departemen Welding.

4. Mengurangi aktifitas repair yang memakan waktu cukup lama.

\subsubsection{Standarisasi (ACTION)}

Adapun standarisasi yang dilakukan adalah sebagai berikut.

1. Melakukan revisi SOP untuk langkahlangkah kerja yang dilakukan operator dengan menambahkan bagian pengecekan menggunakan papan pengecekan Work Order Sheet saat pengambilan part sebelum disetting dan bagian pengecekan dengan menggunakan display varian saat sebelum proses setting Panel Dash Join Front Floor..

2. Memastikan kondisi display varian Panel Dash dan switch berfungsi dengan baik. Pemeriksaan ini dilakukan saat sebelum dan sesudah proses produksi untuk menjaga kondisi alat tersebut tetap baik. Proses pemeriksaan ini dikontrol dan diawasi oleh Team Leader di jalur Under Front.

3. Melakukan pemeriksaan pada papan keterangan varian pada dolly Panel dash dalam kondisi terpasang. Pemeriksaan dilakukan dengan melakukan pengecekan kondisi papan saat sebelum dan sesudah proses produksi. Penggunaan papan tersebut harus dipatuhi oleh operator yang bertanggung jawab terhadap pos tersebut.

4. Melakukan pengecekan kondisi penempatan dolly agar sesuai dengan identitas penempatan dolly yang telah dibuat. Pengecekan dilakukan secara visual untuk memastikan identitas tersebut masih terlihat jelas.

\section{KESIMPULAN}

Berdasarkan data yang telah dianalisis beserta hasil penelitian yang telah dilakukan, maka dapat diambil kesimpulan sebagai berikut.

1. Faktor-faktor yang menyebabkan terjadinya defect Salah Varian Panel Dash Join Front Floor adalah (1) Faktor Man, berupa operator tidak melakukan pengecekan urutan unit yang diproses sehingga salah dalam pengambilan part; (2) Faktor Methode, berupa penempatan dolly Buffer Stock tertukar dengan dolly reguler sehingga menyebabkan terjadinya jumping proses (pengambilan part yang tidak sesuai urutan) dan Dolly buffer stock tidak memiliki identitas keterangan varian Panel Dash; (3) Faktor Machine, berupa posisi part yang berada di tengah sulit terlihat; dan (4) Faktor Environment, berupa tidak adanya identitas untuk penempatan dolly part Panel Dash dan Front Floor. 
2. Penanggulangan yang dilakukan adalah (1) Kategori Man, dengan membuat papan pengecekan Work Order Sheet; (2) Kategori Methode, dengan mengurangi buffer stock Panel Dash dan menambahkan papan keterangan varian pada dolly Panel Dash; (3) Kategori Machine, dengan menambahkan display pengecekan varian Panel Dash pada jig; dan (4) Kategori Environment, adalah dengan membuat identitas penempatan dolly part.

3. Perbaikan yang dilakukan menyebabkan terjadinya penurunan defect dari sebelumnya 25 defect pada bulan September 2017 sampai dengan Februari 2018 menjadi 0 pada bulan Mei 2018 sampai dengan Juni 2018. Hal ini berdampak pada menurunnya jumlah unit delay akibat defect tersebut dari sebelumnya 25 unit pada bulan September 2017 sampai dengan Februari 2018 menjadi 0 pada bulan Mei 2018 sampai dengan Juni 2018 dan menurunnya jumlah part yang scrap dari sebelumnya 12 pcs pada bulan September 2017 sampai dengan Februari 2018 menjadi 0 pada bulan Mei 2018 sampai dengan Juni 2018.

\section{UCAPAN TERIMAKASIH}

Ucapan terima kasih ditujukan kepada orang tua dan adik adik tercinta yang terus memberikan semangat. Kepada teman-teman seperjuangan TIFOURTEEN yang selalu membantu dan berkontribusi besar dalam penyelesaian penelitian ini.

\section{DAFTAR PUSTAKA}

Amin, Syukron. 2014. Pengantar Manajemen Industri. Yogyakarta: Graha Ilmu

Fandy, Tjiptono \& Anastasia Diana. 2014. Total Quality Management Edisi Revisi. Yogyakarta : ANDI.

Hendy, Tannady. 2015. Pengendalian Kualitas. Yogyakarta: Graha Ilmu

Jong, Feliando Yonatan \& Herry Christian Palit. 2015. Upaya Peningkatan Kualitas Part Upper Cover Dengan Metode PDCA di PT Astra Komponen Indonesia. Jurnal Titra, Vol 3 No 2. Surabaya

M.Nur, Nasution, 2015. Manajemen Mutu Terpadu Edisi Ketiga (Total Quality Management). Bogor : Ghalia Indonesia.

Ong, Andre Wahyu Riyanto. 2015. Implementasi Metode Quality Control Circle Untuk Menurunkan Tingkat Cacat Pada Produk Alloy Wheel. Surabaya

Sukanta. 2017. Analisis Pengendalian Kualitas Proses Pemasangan Numbering Clock Dengan Pendekatan Metode Quality Control Circle Perusahaan XYZ. Karawang.

Vincent, Gaspersz,. 2014. Total Quality Management. Jakarta : PT Gramedia Pustaka Utama 